Brazilian Journal of Animal Science ISSN 1806-9290

www.rbz.org.br
Brasileira de Zootecnia
*Corresponding author:

cclway@yahoo.com.br

Received: May 14, 2018

Accepted: August 8, 2018

How to cite: Silva, J. C. R.; Rabello, C. B. V.; Ludke, M. C. M. M.; Lopes, C. C.; Arruda, E. M. F.; Lopes,

E. C.; Oliveira, C. R. C. and Oliveira, C. J. P. 2019. Enzyme complex at different levels in diets with enriched ingredients for commercial laying hens. Revista Brasileira de Zootecnia 48:e20180109. https://doi.org/10.1590/rbz4820180109

Copyright: This is an open access article distributed under the terms of the Creative Commons Attribution License (http://creativecommons.org/licenses/by/4.0/) which permits unrestricted use, distribution, and reproduction in any medium, provided the original work is properly cited.

\section{Enzyme complex at different levels in diets with enriched ingredients for commercial laying hens}

\author{
Jaqueline de Cássia Ramos da Silva ${ }^{1}$ iD, Carlos Bôa-Viagem Rabello ${ }^{1}$ (iD), \\ Maria do Carmo Mohaupt Marques Ludke ${ }^{1}$ (iD), Cláudia da Costa Lopes ${ }^{2 *}$ (iD, \\ Emmanuele Maria Florêncio de Arruda ${ }^{1}$ (iD, Elainy Cristina Lopes ${ }^{1}$ (iD), \\ Camilla Roana Costa de Oliveira $^{1}$ (iD, Cláudio José Parro de Oliveira $^{3}$ iD \\ ${ }^{1}$ Universidade Federal Rural de Pernambuco, Departamento de Zootecnia, Programa de \\ Pós-graduação em Zootecnia, Recife, PE, Brasil. \\ ${ }^{2}$ Universidade Federal do Amazonas, Instituto de Ciências Sociais, Educação e Zootecnia, \\ Departamento de Zootecnia, Parintins, AM, Brasil. \\ ${ }^{3}$ Universidade Federal de Sergipe, Departamento de Zootecnia, Campos Sertão, Nossa \\ Senhora da Glória, SE, Brasil.
}

\begin{abstract}
The objective of this study was to evaluate levels of inclusion of an enzyme complex (EC) in corn- and soybean meal-based diets for laying hens on the digestibility of nutrients and energy. A metabolism trial was conducted using 75 Dekalb Brown laying hens at 26 weeks of age, which were distributed into five treatments with five replicates in a completely randomized design. The ingredients used in the diets received an additional (enriched) 3\% methionine, lysine, cysteine, threonine, tryptophan, and metabolizable energy and $33.3 \%$ phosphorus. Treatments consisted of diets including $0,150,200,250$, or $300 \mathrm{mg} \cdot \mathrm{kg}^{-1} \mathrm{EC}$. We determined apparent metabolizable energy (AME); nitrogen-corrected AME (AMEn); apparent metabolizability coefficients of dry matter $\left(\mathrm{DM}_{\mathrm{AM}}\right)$, crude protein $\left(\mathrm{CP}_{\mathrm{AM}}\right)$, gross energy $\left(\mathrm{GE}_{\mathrm{AM}}\right)$, and phosphorus $\left(\mathrm{P}_{\mathrm{AM}}\right)$; digestible crude protein $\left(\mathrm{CP}_{\mathrm{D}}\right)$; and intake, retention, and excretion of phosphorus. No effects of EC levels were detected on the metabolizable energy values or digestibility coefficients, except for $\mathrm{CP}_{\mathrm{AM}}$, which showed a quadratic response (maximum coefficient at $89.0 \mathrm{mg} \cdot \mathrm{kg}^{-1} \mathrm{EC}$ ). A quadratic effect was also observed for $\mathrm{CP}_{\mathrm{D}}$ (minimum at $115 \mathrm{mg} \cdot \mathrm{kg}^{-1} \mathrm{EC}$ ), $\mathrm{P}$ excretion (maximum at $173.2 \mathrm{mg} \cdot \mathrm{kg}^{-1} \mathrm{EC}$ ), and $\mathrm{P}$ retention (maximum at $122.4 \mathrm{mg} \cdot \mathrm{kg}^{-1} \mathrm{EC}$ ) when EC was used. The use of the EC in corn- and soybean meal-based diets for laying hens improves their ileal digestibility of protein and apparent digestibility of phosphorus. However, EC addition to the diets does not affect AME, AMEn, or their metabolizability coefficients.
\end{abstract}

Keywords: digestibility, enzymes, hens, nutrients

\title{
Introduction
}

The use of enzymes reduces the negative impact of indigestible residues on the viscosity of the digesta (Buchanan et al., 2007). Non-starch polysaccharides (NSP) have a high water-holding capacity, forming polymers or gels that hamper enzymatic action, as they form a gelatinous substance in the intestinal tract (Lima et al., 2007).

Moreover, birds are not able to synthesize some enzymes or produce them in insufficient amounts, requiring supplementation for the digestion of the many chemical components found in plant-based foods or some anti-nutritional processes, e.g., phytate (Costa et al., 2007). 
Enzyme additives do not have a direct nutritional function, but they act by helping the digestive process and improving the digestibility of dietary nutrients (Guimarães et al., 2009). Because each enzyme has a specific reaction to certain substrates, the use of compound additives from a single enzyme may be sufficient for a nutrient to be utilized to its maximum extent, which suggests that enzyme mixtures are more effective for the utilization of the many dietary nutrients (Murakami et al., 2007).

The use of enzymatic complexes favors the degradation of NSP, improving the utilization of the dietary energy by increasing the release of the energy contained in the ingredients. In this way, it is possible to reduce the amount of ingredients used in feed formulations, since the enzymes will aid in the release of the nutrients that were then unavailable to the animal. Additionally, enzymes play the role of hampering the formation of binary complexes between the protein and phytate, leading to a greater utilization of phosphorus and amino acids, which occurs as a result of the disruption of the cell walls of dietary ingredients (Tavernari et al., 2008).

According to Liu et al. (2007), plant ingredients have anti-nutritional factors and/or substances that are not digested by digestive enzymes of birds, and the use of specific enzymes in diets allows for a reduction or even elimination of substances that can potentially pollute the environment such as phosphorus and nitrogen, in addition to lowering the feed cost.

The objective of this study was to evaluate the effects of inclusion of different levels of an enzyme complex in corn- and soybean meal-based diets for laying hens on nutrient and energy digestibility.

\section{Material and Methods}

The research was conducted in Recife, PE, Brazil (8॰02'10"S and 34 $4^{\circ} 5^{\prime} 39^{\prime \prime} \mathrm{W}, 18 \mathrm{~m}$ asl), after approval by the local Ethics Committee of Animal Use (case no. 23082.006383/2015-57). The experiment lasted 10 days (five days for adaptation and five days for excreta collection).

Seventy-five Dekalb Brown laying hens at 26 weeks of age were housed in metabolic cages (dimensions: $1.00 \mathrm{~m}$ length $\times 0.50 \mathrm{~m}$ width $\times 0.50 \mathrm{~m}$ height), in a completely randomized design with five treatments and five replicates of three birds per cage.

The lighting program adopted during the experimental period was $16 \mathrm{~h}$ of light daily. During the experimental period, the recorded maximum, minimum, and mean temperatures were $30,24.5$, and $27.5^{\circ} \mathrm{C}$, respectively, and the average relative air humidity was $66 \%$. Water and feed were available ad libitum throughout the experiment.

Treatments were constituted as follows: T1 - corn- and soybean meal-based control diet enriched with an additional amount of $3 \%$ of its chemical composition, with no inclusion of enzyme complex; T2 - control diet supplemented with $150 \mathrm{mg} \cdot \mathrm{kg}^{-1}$ of an enzyme complex; T3 - control diet supplemented with $200 \mathrm{mg} \cdot \mathrm{kg}^{-1}$ of an enzyme complex; T4 - control diet supplemented with $250 \mathrm{mg} \cdot \mathrm{kg}^{-1}$ of an enzyme complex; and T5 - control diet supplemented with $300 \mathrm{mg} \cdot \mathrm{kg}^{-1}$ of an enzyme complex. The lowest inclusion level tested in this study agreed with the recommendation of the manufacturer.

The enzyme complex contained pectinase $\left(1,259.26 \mathrm{U}^{-1}\right)$, cellulase $\left(27.35 \mathrm{U} \cdot \mathrm{mL}^{-1}\right)$, phytase (2.06 $\left.\mathrm{U.g}^{-1}\right), \beta$-glucanase $\left(516.66 \mathrm{U.kg}^{-1}\right)$, xylanase $\left(77.47 \mathrm{U.g}^{-1}\right)$, protease $\left(295.56 \mathrm{U.mL}^{-1}\right)$, and amylase (15.53 U. $\mathrm{mL}^{-1}$ ). One unit of enzymatic activity (U) is defined as the amount of enzyme necessary to produce $1 \mathrm{mmol}$ glucose $\mathrm{mL} \cdot \mathrm{min}^{-1}$. The control diet (Table 1 ) was formulated according to the nutritional requirements of the birds, following the food-composition tables proposed by Rostagno et al. (2011). The enzyme complex was added to the diets replacing the inert (washed sand pre-dried in a forced-air oven for $24 \mathrm{~h}$ ).

The nutrients in corn and soybean meal were enriched as follows (Table 2): $3 \%$ in the contents of metabolizable energy, crude protein, and the first five limiting amino acids (methionine, lysine, cystine, threonine, and tryptophan); and 33.3\% in available-phosphorus contents.

R. Bras. Zootec., 48:e20180109, 2019 
Table 1 - Composition and nutritional values of experimental diets

\begin{tabular}{lllc}
\hline Ingredient $\left(\mathrm{g} \mathrm{kg}^{-1}\right)$ & & \multicolumn{2}{c}{ Calculated composition $\left(\mathrm{g} \mathrm{kg}^{-1}\right)$} \\
\hline Corn & 638.1 & AMEn $\left(\mathrm{kcal} . \mathrm{kg}^{-1}\right)$ & 2,900 \\
Soybean meal & 229.2 & Crude protein & 152.4 \\
Soybean oil & 15.1 & Calcium & 38.53 \\
Limestone & 94.7 & Available phosphorus & 2.75 \\
Dicalcium phosphate & 8.39 & Total phosphorus & 2.55 \\
Salt $(\mathrm{NaCl})$ & 4.60 & Lysine & 7.54 \\
Vitamin + mineral premix & (1) & Methionine & 4.59 \\
L-lysine HCl, 78.8 & 1.00 & Methionine + cystine & 6.86 \\
DL-methionine, 99 & 0.28 & Threonine & 5.73 \\
L-threonine, 98.5 & 2.33 & Tryptophan & 1.73 \\
L-tryptophan, 98.5 & 0.25 & Fat & 42.10 \\
Celite & 0.03 & Crude fiber & 23.21 \\
Inert & 5.00 & Sodium & 2.00 \\
Enzyme complex & 1.30 & Potassium & 6.04 \\
Total & 0.00 & Chlorine & 3.24 \\
\hline
\end{tabular}

AMEn - nitrogen-corrected apparent metabolizable energy.

1 Amount/kg of product: vitamin A, 8,000,000 IU; vitamin D3, 2,000,000 IU; vitamin E, 15,000 mg; vitamin K3, 1,960 mg; vitamin B2, 4,000 mg; vitamin B6, 1,000 mg; vitamin B12, 10,000 mcg; niacin, 19,800 mg; pantothenic acid, 5,350 mg; folic acid, $200 \mathrm{mg}$; manganese, 32,500 mg; zinc, 5,000 mg; iron, 20,000 mg; copper, 4,000 mg; iodine, 1,500 mg; selenium, $250 \mathrm{mg}$; cobalt, $200 \mathrm{mg}$; antioxidant, $100,000 \mathrm{mg}$.

2 Values determined at the laboratory.

Table 2 - Composition of enriched or unenriched ingredients used in the formulation of the experimental diets

\begin{tabular}{|c|c|c|c|c|}
\hline Nutrient $\left(\mathrm{g} \mathrm{kg}^{-1}\right)$ & Grain corn & $3 \%$ enrichment & Soybean meal & $3 \%$ enrichment \\
\hline ME (kcal.kg-1) & $3,381.0$ & $3,482.4$ & $2,254.0$ & $2,321.6$ \\
\hline Crude protein & 78.8 & 81.16 & 450.0 & 463.5 \\
\hline $\mathrm{Ca}$ & 0.30 & 0.31 & 2.40 & 2.47 \\
\hline Available $\mathrm{P}^{1}$ & 0.60 & 0.80 & 2.20 & 2.93 \\
\hline Methionine & 1.50 & 1.55 & 5.50 & 5.67 \\
\hline Methionine + cystine & 2.90 & 2.99 & 11.30 & 11.64 \\
\hline Lysine & 1.90 & 1.96 & 25.70 & 26.47 \\
\hline Threonine & 2.70 & 2.78 & 15.70 & 16.17 \\
\hline Tryptophan & 0.50 & 0.52 & 5.80 & 5.97 \\
\hline Arginine & 3.40 & 3.50 & 31.70 & 32.65 \\
\hline Phenylalanine + tyrosine & 5.80 & 5.97 & 37.30 & 38.42 \\
\hline Leucine & 9.00 & 9.27 & 31.90 & 32.86 \\
\hline Valine & 3.30 & 3.40 & 19.70 & 20.29 \\
\hline Phenylalanine & 3.40 & 3.50 & 21.80 & 22.45 \\
\hline Isoleucine & 2.40 & 2.47 & 19.20 & 19.78 \\
\hline Histidine & 2.10 & 2.16 & 11.20 & 11.54 \\
\hline Fat & 36.50 & 37.60 & 16.90 & 17.41 \\
\hline Linolenic acid & 19.10 & 19.67 & 8.90 & 9.17 \\
\hline $\mathrm{Na}$ & 0.20 & 0.21 & 0.20 & 0.21 \\
\hline $\mathrm{Cl}$ & 0.60 & 0.62 & 0.50 & 0.52 \\
\hline $\mathrm{K}$ & 2.90 & 2.99 & 18.30 & 18.85 \\
\hline Crude fiber & 17.30 & 17.82 & 53.00 & 54.59 \\
\hline
\end{tabular}

ME - metabolizable energy.

${ }^{1}$ Digestible phosphorus enriched with $33.3 \%$. 
Iron oxide powder was added at the level of $2 \%$ to the experimental diets as a marker at the beginning and end of excreta collection period; the excreta non-marked on the first collection day and those marked on the last day were discarded. Metabolic cages containing trays coated with plastic were used for total excreta collection. Total excreta collection was carried out to determine the apparent digestibility coefficients of dry matter, crude protein, gross energy, and phosphorus, as well as the apparent metabolizable energy (AME) and the nitrogen-corrected AME (AMEn). For the samples of ileal content, we determined the ileal digestibility of dry matter and crude protein.

At the end of the experimental period, all birds were sacrificed by cervical dislocation, followed by an abdominal section and exposure of the ileum to harvest the ileal content. Samples of ileal content and excreta were identified, placed in plastic bottles, frozen at $-20^{\circ} \mathrm{C}$, and later pre-dried in a forced-air oven at $55{ }^{\circ} \mathrm{C}$. Samples of feed, excreta, and ileal content were ground and sent to the laboratory to determine the dry matter and nitrogen contents according to methodologies described by Silva and Queiroz (2002). Energy analyses were carried out using an IKA C2000 calorimeter. Phosphorus analyses were performed using a UV-380G spectrophotometer. Lastly, the acid-insoluble ash concentrations in the excreta, ileal-content, and experimental-diet samples were determined by a methodology adapted from Van Keulen and Young (1977).

To determine the metabolizability values and its coefficients, feed intake was calculated after measuring the amount of feed supplied and the leftovers. The amount of excreta generated by the birds was also quantified during the collection period.

Based on the results of the laboratory analyses, we calculated the AME and AMEn using equations proposed by Matterson et al. (1965), as well as the apparent metabolizability coefficients of dry matter $\left(\mathrm{DM}_{\mathrm{AM}}\right)$, gross energy $\left(\mathrm{GE}_{\mathrm{AM}}\right)$, crude protein $\left(\mathrm{CP}_{\mathrm{AM}}\right)$, and phosphorus $\left(\mathrm{P}_{\mathrm{AM}}\right)$

The data were checked for the presence of outliers and errors, and variance-homogeneity assumptions were tested. After these assumptions were found to be met, the data were subjected to an analysis of variance followed by regression analysis at the $5 \%$ probability level using the SISVAR computer package version 4.6. (Ferreira, 2003).

\section{Results}

Mean values for metabolizable energy and digestibility coefficients of dry matter, crude protein, and gross energy were not significantly affected by the enzyme-complex levels (Table 3 ). No significant effects were observed for the digestibility coefficient of crude protein, apparent metabolizable energy, or apparent metabolizable energy corrected for the nitrogen balance, either.

An improvement in protein utilization could be observed based on the results obtained for digestible protein, as the ileal-digestibility and the digestible-protein values better represent the nutritional utilization of the diets by the animals, considering that no microbial fermentation had yet occurred in the cecum of birds (Table 4).

Table 3 - Apparent digestibility coefficients of dry matter $\left(\mathrm{DM}_{\mathrm{AD}}\right)$, crude protein $\left(\mathrm{CP}_{\mathrm{AD}}\right)$, and gross energy $\left(\mathrm{GE}_{\mathrm{AD}}\right)$; apparent metabolizable energy (AME); and nitrogen-corrected apparent metabolizable energy (AMEn) of diets containing different levels of an enzyme complex for layers

\begin{tabular}{|c|c|c|c|c|c|c|c|c|c|}
\hline & \multicolumn{5}{|c|}{ Enzyme complex level (mg.kg ${ }^{-1}$ ) } & \multirow{2}{*}{$\mathrm{RE}$} & \multirow{2}{*}{$\mathrm{P}$} & \multirow{2}{*}{ SD } & \multirow{2}{*}{$\mathrm{CV} \%$} \\
\hline & 0 & 150 & 200 & 250 & 300 & & & & \\
\hline $\mathrm{DM}_{\mathrm{AD}}(\%)$ & 76.10 & 75.08 & 75.69 & 75.80 & 76.19 & ns & 0.996 & 4.73 & 6.16 \\
\hline $\mathrm{CP}_{\mathrm{AD}}(\%)$ & 86.29 & 86.97 & 86.42 & 85.71 & 87.15 & ns & 0.981 & 3.68 & 4.69 \\
\hline $\mathrm{GE}_{\mathrm{AD}}(\%)$ & 78.75 & 78.68 & 78.79 & 78.98 & 79.31 & ns & 0.978 & 2.40 & 2.17 \\
\hline AME (kcal) & 2,862 & 3,028 & 3,047 & 3,133 & 3,067 & ns & 0.804 & 121 & 12.03 \\
\hline AMEn (kcal) & 2,765 & 2,982 & 2,940 & 3,033 & 2,962 & ns & 0.791 & 100 & 11.94 \\
\hline
\end{tabular}

$\mathrm{RE}$ - regression equation; P - probability; SD - standard deviation; CV - coefficient of variation; ns - not significant. 
There was no significant effect of enzyme-complex inclusion on the ileal digestibility of dry matter and protein or on digestible dry matter. This indicates that the total absorption of nutrients was similar across all diets. Digestible crude protein, however, responded quadratically, with improved digestibility at enzyme complex levels greater than $115 \mathrm{mg} \cdot \mathrm{kg}^{-1}$.

Results found in this study for phosphorus intake were not significant. However, the excretion, retention, and digestibility coefficient of phosphorus had a quadratic response (Table 5). Maximum phosphorus excretion occurred with supplementation of $173.2 \mathrm{mg} \cdot \mathrm{kg}^{-1}$ of enzyme complex; maximum retention at $122.5 \mathrm{mg} \cdot \mathrm{kg}^{-1}$; and the highest apparent digestibility coefficient of the element was found at the level of $89.0 \mathrm{mg} \cdot \mathrm{kg}^{-1}$ of enzyme complex supplementation.

\section{Discussion}

In view of the obtained results, we may state that the level of enzyme complex added to the diets does not influence the digestibility coefficients or energy values of laying-hen diets. The increasing enzyme levels might have made more nutrients available; however, the organism of the birds was unable to fully metabolize them, or the amount of substrate available for enzymatic action might have been lower than the amount of enzymes present, since enzymes are substrate-dependent.

Viana et al. (2009) also did not find a significant effect on the apparent digestibility coefficient of dry matter in diets supplemented with $100 \mathrm{mg} \cdot \mathrm{kg}^{-1}$ of the Rovábio ${ }^{\circledR}$ Max multi-enzyme complex for layers $(\mathrm{P}>0.05)$. Likewise, there was no significant effect of the diets on the metabolizability coefficient of gross energy, AME, or AMEn. Freitas et al. (2000) enriched diets for commercial layers with energy exclusively, adding $100 \mathrm{mg} \cdot \mathrm{kg}^{-1}$ enzyme complex to them, and did not find significant differences in their performance or feed costs.

Table 4 - Ileal digestibility coefficients of dry matter $\left(\mathrm{DM}_{\mathrm{IDC}}\right)$ and crude protein $\left(\mathrm{CP}_{\mathrm{IDC}}\right)$, digestible dry matter $\left(\mathrm{DM}_{\mathrm{D}}\right)$, and digestible crude protein $\left(\mathrm{CP}_{\mathrm{D}}\right)$ of diets containing different levels of an enzyme complex for layers

\begin{tabular}{|c|c|c|c|c|c|c|c|c|c|}
\hline & \multicolumn{5}{|c|}{ Enzyme complex level (mg.kg-1) } & \multirow{2}{*}{ EQ } & \multirow{2}{*}{$\mathrm{P}$} & \multirow{2}{*}{ SD } & \multirow{2}{*}{$\mathrm{CV} \%$} \\
\hline & 0 & 150 & 200 & 250 & 300 & & & & \\
\hline $\mathrm{DM}_{\mathrm{IDC}}(\%)$ & 82.83 & 84.18 & 86.08 & 84.33 & 84.22 & ns & 0.153 & 2.15 & 1.56 \\
\hline $\mathrm{DM}_{\mathrm{D}}\left(\mathrm{g} \cdot \mathrm{kg}^{-1}\right)$ & 746.72 & 758.65 & 768.63 & 756.49 & 754.49 & ns & 0.388 & 18.55 & 1.56 \\
\hline $\mathrm{CP}_{\mathrm{IDC}}(\%)$ & 86.09 & 87.17 & 89.83 & 87.07 & 88.12 & ns & 0.060 & 2.02 & 1.30 \\
\hline $\mathrm{CP}_{\mathrm{D}}\left(\mathrm{g} \cdot \mathrm{kg}^{-1}\right)$ & 152.5 & 152.24 & 158.95 & 150.08 & 152.32 & $\mathrm{Q}^{1}$ & 0.041 & 3.90 & 1.27 \\
\hline
\end{tabular}

EQ - equation; P - probability; SD - standard deviation; CV - coefficient of variation; ns - not significant; Q - quadratic equation; $\mathrm{R}^{2}$ - coefficient of determination.

${ }^{1} \mathrm{CP}_{\mathrm{D}}=152.394484-0.03315 \mathrm{X}+0.000144 \mathrm{X}^{2}\left(\mathrm{R}^{2}=0.58\right)$.

Table 5 - Intake $\left(\mathrm{P}_{\text {int }}\right)$, excretion $\left(\mathrm{P}_{\text {exc }}\right)$, retention $\left(\mathrm{P}_{\text {ret }}\right)$, and apparent digestibility coefficient $\left(\mathrm{P}_{\mathrm{AD}}\right)$ of phosphorus in diets containing different levels of an enzyme complex for layers

\begin{tabular}{|c|c|c|c|c|c|c|c|c|c|}
\hline & \multicolumn{5}{|c|}{ Enzyme complex level (mg.kg-1) } & \multirow{2}{*}{ EQ } & \multirow{2}{*}{$\mathrm{P}$} & \multirow{2}{*}{ SD } & \multirow{2}{*}{ CV\% } \\
\hline & 0 & 150 & 200 & 250 & 300 & & & & \\
\hline$P_{\text {int }}(g)$ & 0.34 & 0.45 & 0.35 & 0.42 & 0.44 & ns & 0.0260 & 0.06 & 13.66 \\
\hline$P_{e x c}(g)$ & 0.22 & 0.26 & 0.25 & 0.31 & 0.34 & $Q^{1}$ & 0.0008 & 0.05 & 14.10 \\
\hline$P_{\text {ret }}(g)$ & 0.11 & 0.18 & 0.10 & 0.11 & 0.10 & $Q^{2}$ & 0.0240 & 0.06 & 26.15 \\
\hline $\mathrm{P}_{\mathrm{AD}}(\%)$ & 34.74 & 41.43 & 30.13 & 25.97 & 23.09 & $\mathrm{Q}^{3}$ & 0.0009 & 7.82 & 17.84 \\
\hline
\end{tabular}

EQ - equation; P - probability; SD - standard deviation; CV - coefficient of variation; ns - not significant; Q - quadratic equation; $\mathrm{R}^{2}$ - coefficient of determination.

${ }^{1} \mathrm{P}_{\text {exc }}=0.22434+0.00005196 \mathrm{X}-0.000000150 \mathrm{X}^{2}\left(\mathrm{R}^{2}=0.57\right)$.

${ }^{2} \mathrm{P}=0.12230+0.00051684 \mathrm{X}-0.00000211 \mathrm{X}^{2}\left(\mathrm{R}^{2}=0.36\right)$

${ }^{3} \mathrm{P}_{\mathrm{AD}}^{\mathrm{ret}}=35.38915+0.06966 \mathrm{X}-0.00039189 \mathrm{X}^{2}\left(\mathrm{R}^{2}=0.56\right)$. 
Silva et al. (2012) studied the association of $100 \mathrm{mg} \cdot \mathrm{kg}^{-1}$ carbohydrase and $30 \mathrm{mg} \cdot \mathrm{kg}^{-1}$ phytase in feed for commercial brown-egg layers using a diet without enzymes and test diets enriched with energy and nutrients according to the nutrient matrix and of enzymes did not find a significant effect of treatments on the performance of birds. The authors attributed this effect to the good metabolic utilization of the diets containing enzyme supplementation.

In an experiment in which layer diets were supplemented with phytase, considering the nutrient matrix of the enzyme, Silversides and Hruby (2009) observed decreases of the order of 34 and $47 \mathrm{kcal}^{\mathrm{kg}}{ }^{-1}$ of apparent metabolizable energy, 0.18 and $0.21 \%$ of crude protein, and 0.12 and $0.15 \%$ of available $P$ with the use of 300 and 600 FTU. $\mathrm{kg}^{-1}$ phytase, respectively. The authors concluded that phytase provides additional benefits to the availability of other nutrients besides phosphorus, mainly protein and energy.

The present results corroborate those obtained by Viana et al. (2011), who concluded that there are no differences in the metabolizability coefficients of dry matter and metabolizable energy of Bovans Goldline layers fed corn- and soybean-based diets with two levels of metabolizable energy 2,900 and $2,755 \mathrm{kcal}^{\mathrm{kg}}{ }^{-1}$ ) with or without xylanase inclusion (Econase XT25 ${ }^{\circledR}$ ).

Strada et al. (2005) also used an enzyme complex at the rate of $155 \mathrm{ppm}$ in a diet enriched with 5 and $7 \%$ amino acids and 7 and 9\% metabolizable energy and did not find significant differences in the growth of broilers fed diets containing corn, soybean meal, and sorghum or pearl millet. Pourreza et al. (2007) worked with different levels of an enzyme complex $\left(0,100,200,400\right.$, and $\left.800 \mathrm{mg} \cdot \mathrm{kg}^{-1}\right)$ supplementing a corn- and soybean meal-based diet also for broilers and did not observe differences among the treatments for the metabolization coefficients of crude protein and dry matter.

In this regard, Strada et al. (2005) stated that the effect of an enzyme on the digestibility of proteins is more related to the reduced loss of endogenous amino acids than to a better digestion of the dietary protein itself, i.e., the enzyme supplementation of proteases is related to the decrease in their endogenous synthesis. Therefore, the animal spares energy for the synthesis of enzymes, and this energy can be rerouted for production.

Dourado et al. (2009) evaluated the effect of corn- and soybean meal-based diets with or without enzyme complex supplementation (phytase, xylanase, amylase, and protease) or enzymes in isolated form on the ileal digestibility of dry matter and observed that enzyme addition (isolated or as a complex) was efficient in improving the dry matter digestibility of broiler diets.

Freitas et al. (2011) found no effect of protease supplementation in corn- and soybean meal-based diets for broilers on their digestibility of crude protein or gross energy. Those authors worked with a reduction of $4.4 \%$ in the levels of crude protein and metabolizable energy.

The higher phosphorus excretion may be a consequence of larger amounts of this mineral provided in the diets with increasing levels of the enzyme complex, resulting from the greater participation of phytase. Similar findings were reported by Viana et al. (2009), who used the multi-enzyme complex Rovábio $^{\circledR}$ Max at the rate of $100 \mathrm{mg} \cdot \mathrm{kg}^{-1}$ in enriched and unenriched diets for layers.

Based on the data presented by Olukosi et al. (2007), glycosidases degrade the NSP layers of the cell membrane, which facilitates the access of phytase to the phytate stored in the cell wall membrane. Those authors found improved nutrient digestibility with an enzymatic combination of phytase and a complex containing amylase, xylanase, and protease, in broiler diets.

Meneghetti et al. (2011) worked with phytase supplementation at levels starting at $450 \mathrm{mg} \cdot \mathrm{kg}^{-1}$ diet with a nutritional reduction in the dietary energy and concluded that it can be used in broilers from 1 to 35 days of age without any harm to their nutrient digestibility and energy utilization.

Liebert et al. (2005) experimented phytase supplementation $\left(300 \mathrm{mg} \cdot \mathrm{kg}^{-1}\right)$ in corn- and soybean mealor wheat bran- and soybean meal-based diets for commercial layers and found no effect on their intake, retention, and excretion of phosphorus. Scheideler et al. (2005), in turn, evaluated inclusion or absence of the enzyme complex Avizime $1500^{\circledR}$ (composed of xylanase, $\alpha$-amylase, and protease) in corn- and soybean meal-based diets with two levels of metabolizable energy $(2,890$ and 2,805 kcal.kg-1) for commercial layers (Babcock B-300 and Hy-line w-36) from 25 to 40 weeks of age and observed that 
enzyme supplementation significantly increased the retention of protein and calcium $(\mathrm{P}<0.05)$ but had a negative effect $(\mathrm{P}<0.05)$ on the retention of phosphorus.

According to Wang et al. (2006), the use of enzymes improves the utilization of feedstuffs, thereby allowing for a reduction in the inclusion of certain nutrients, e.g., amino acids and minerals. This fact could be demonstrated in the present study, in which no alteration occurred in phosphorus intake, although an increase in the enzyme-complex levels raised the retention and excretion of that mineral.

\section{Conclusions}

The use of an enzyme complex containing pectinase, cellulase, phytase, $\beta$-glucanase, xylanase, protease, and amylase in corn- and soybean meal-based diets for layers improves their ileal digestibility of protein and apparent digestibility of phosphorus. However, the addition of that complex to the diets does not have any effect on apparent metabolizable energy, nitrogen-corrected apparent metabolizable energy, or its metabolizability coefficients.

\section{Acknowledgments}

The authors thank the Conselho Nacional de Desenvolvimento Científico e Tecnológico (CNPq), Coordenação de Aperfeiçoamento de Pessoal de Nível Superior (CAPES), Universidade Federal Rural de Pernambuco, and Bioenzima ${ }^{\circledR}$ company, for the research funds.

\section{References}

Buchanan, N. P.; Kimbler, L. B.; Parsons, A. S.; Seidel, G. E.; Bryan, W. B.; Felton, E. E. D. and Moritz, J. S. 2007. The effects of nonstarch polysaccharide enzyme addition and dietary energy restriction on performance and carcass quality of organic broiler chickens. The Journal of Applied Poultry Research 16:1-12. https://doi.org/10.1093/japr/16.1.1

Costa, F. G. P.; Brandão, P. A.; Brandão, J. S. and Silva, J. H. V. 2007. Efeito da enzima fitase nas rações de frangos de corte, durante as fases pré-inicial e inicial. Ciência e Agrotecnologia 31:865-870. https://doi.org/10.1590/S1413-70542007000300037

Dourado, L. R. B.; Sakomura, N. K.; Barbosa, N. A. A.; Bonato, M. A.; Kawuauchi, I. M.; Fernandes, J. B. K. and Costa, F. G. P. 2009. Corn and soybean meal metabolizable energy with the addition of exogenous enzymes for poultry. Revista Brasileira de Ciência Avícola 11:51-55. https://doi.org/10.1590/S1516-635X2009000100008

Ferreira, D. F. 2003. Programa SISVAR. Sistema de Análise de Variância. Versão 4.6 (Build 6.0). DEX/UFLA, Lavras.

Freitas, D. M.; Vieira, S. L.; Angel, C. R; Favero, A. and Maiorka, A. 2011. Performance and nutrient utilization of broilers fed diets supplemented with a novel mono-component protease. The Journal of Applied Poultry Research 20:322-334. https://doi.org/10.3382/japr.2010-00295

Freitas, E. R.; Fuentes, M. F. F. and Espíndola, G. B. 2000. Efeito da suplementação enzimática em rações à base de milho/farelo de soja sobre o desempenho de poedeiras comerciais. Revista Brasileira de Zootecnia 29:1103-1109. https://doi.org/10.1590/S1516-35982000000400022

Guimarães, I. G.; Falcon, D. R.; Schich, D.; Barros, M. M. and Pezzato, L. E. 2009. Digestibilidade aparente de rações contendo complexo enzimático para tilápia-do-nilo. Arquivo Brasileiro de Medicina Veterinária e Zootecnia 61:1397-1402. https://doi.org/10.1590/S0102-09352009000600020

Liebert, F.; Htoo, J. K. and Sünder, A. 2005. Performance and nutrient utilization of laying hens fed low-phosphorus corn-soybean and wheat-soybean diets supplemented with microbial phytase. Poultry Science 84:1576-1583. https://doi.org/10.1093/ps/84.10.1576

Lima, M. R.; Silva, J. H. V.; Araujo, J. A.; Lima, C. B. and Oliveira, E. R. A. 2007. Enzimas exógenas na alimentação de aves. Acta Veterinária Brasilica 1:99-110.

Liu, N.; Liu, G. H.; Li, F. D.; Sands, J. S.; Zhang, S.; Zheng, A. J. and Ru, Y. J. 2007. Efficacy of phytases on egg production and nutrient digestibility in layers fed reduced phosphorus diets. Poultry Science 86:2337-2342. https://doi.org/10.3382/ps.2007-00079

Matterson, L. D.; Potter, L. M. and Stutz, M. W. 1965. The metabolizable energy of feed ingredients for chickens. Agricultural Experimental Station Research Report 7:3-11.

Meneghetti, C.; Bertechini, A. G.; Rodrigues, P. B.; Fassani, E. J.; Brito, J. A. G.; Reis, M. P. and Garcia Jr, A. A. P. 2011. Altos níveis de fitase em rações para frangos de corte. Arquivo Brasileiro de Medicina Veterinária e Zootecnia 63:624-632. https://doi.org/10.1590/S0102-09352011000300014

R. Bras. Zootec., 48:e20180109, 2019 
Murakami, A. E.; Fernandes, J. I. M.; Sakamoto, M. I.; Sousa, L. M. G. and Furlan, A. C. 2007. Efeito da suplementação enzimática no desempenho e qualidade dos ovos de poedeiras comerciais. Acta Scientiarum. Animal Sciences 29:165-172.

Olukosi, O. A.; Cowieson, A. J. and Adeola, 0. 2007. Age-related influence of a cocktail of xylanase, amylase, and protease or phytase individually or in combination in broilers. Poultry Science 86:77-86.

Pourreza, J.; Samie, A. H. and Rowghani, E. 2007. Effect of supplemental enzyme on nutrient digestibility and performance of broiler chicks fed on diets containing triticale. International Journal of Poultry Science 6:115-117. https://doi.org/10.3923/ijps.2007.115.117

Rostagno, H. S.; Albino, L. F. T.; Donzele, J. L.; Gomes, P. C.; Oliveira, R. F.; Lopes, D. C.; Ferreira, A. S.; Barreto, S. L. T. and Euclides, R. F. 2011. Tabelas brasileiras para aves e suínos: composição de alimentos exigências nutricionais. 3.ed. UFV, DZO, Viçosa, MG

Scheideler, S. E.; Beck, M. M.; Abudabos, A. and Wyatt, C. L. 2005. Multiple-enzyme (Avizyme) supplementation of corn-soy-based layer diets. Journal of Applied Poultry Research 14:77-86. https://doi.org/10.1093/japr/14.1.77

Silva, D. J. and Queiroz, A. C. 2002. Análise de alimentos (métodos químicos e biológicos). 3.ed. UFV, Viçosa, MG.

Silva, L. M.; Geraldo, A.; Vieira Filho, J. A.; Machado, L. C.; Brito, J. A. G. and Bertechini, A. G. 2012. Associação de carboidrase e fitase em dietas valorizadas para poedeiras semipesadas. Acta Scientiarum. Animal Sciences 34:253-258.

Silversides, F. G. and Hruby, M. 2009. Feed formulation using phytase in laying hen diets. Journal of Applied Poultry Research 18:15-22. https://doi.org/10.3382/japr.2008-00035

Strada, E. S. O.; Abreu, R. D.; Oliveira, G. J. C.; Costa, M. C. M. M.; Carvalho, G. J. L.; Franca, A. S.; Clarton, L. and Azevedo, J. L. M. 2005. Uso de enzimas na alimentação de frangos de corte. Revista Brasileira de Zootecnia 34:2369-2375. https://doi.org/10.1590/S1516-35982005000700024

Tavernari, F. C.; Carvalho, T. A.; Assis, A. P. and Lima, H. J. D. 2008. Polissacarídeos não amiláceos solúveis na dieta de suínos e aves. Revista Eletrônica Nutritime 5:673-689.

Van Keulen, J. and Young, B. A. 1977. Evaluation of acid insoluble ash as natural marker in ruminant digestibility studies. Journal of Animal Science 44:282-287. https://doi.org/10.2527/jas1977.442282x

Viana, M. T. S.; Albino, L. F. T.; Rostagno, H. S.; Silva, E. A.; Messias, R. K. G. and Pereira, J. P. L. 2009. Efeito do uso de enzimas sobre o desempenho e metabolismo de poedeiras. Revista Brasileira de Zootecnia 38:1068-1073. https://doi.org/10.1590/S1516-35982009000600014

Viana, M. T. S.; Albino, L. F. T.; Rostagno, H. S.; Silva, E. A.; Vieira, R. A. and Ribeiro Junior, V. 2011. Utilização de xilanase em dietas compostas por milho e farelo de soja de poedeiras comerciais em postura. Revista Brasileira de Zootecnia 40:385-390. https://doi.org/10.1590/S1516-35982011000200021

Wang, J. J.; Garlich, J. D. and Shih, J. C. H. 2006. Beneficial effects of versazyme, a keratinase feed additive, on body weight, feed conversion, and breast yield of broilers chickens. Journal of Applied Poultry Research 15:544-550. https://doi.org/10.1093/japr/15.4.544 